\title{
Santral Sinir Sistemi Enfeksiyonlarında, Herpes Simplex Virüs Varlığının Beyin Omurilik Sıvısı Örneklerinde Real-Time PZR Yöntemiyle Araştırılması
}

\author{
Investigation of Presence of Herpes Simplex Virus in Central Nervous \\ System Infections by Real-Time PCR Method in Cerebrospinal Fluid \\ Samples
}

\author{
Nilgün Kaşifoğlu, Müge Aslan, Gül Durmaz, Tercan Us \\ Eskişehir Osmangazi Üniversitesi Tıp Fakültesi Tıbbi Mikrobiyoloji Anabilim Dalı, Eskisehir, \\ Türkiye
}

\begin{abstract}
Özet: Santral sinir sistemi (SSS) enfeksiyonları hızlı ilerleyen, ölüme veya kalıcı sekellere neden olabilen hastalıklardandır. Bu nedenle hızlı tanı büyük önem taşımaktadır. Akut menenjit ve ensefalit etyolojisinde en sık karşılaşılan etken virüslerdir. Bu etkenler arasında Herpes simpleks virüs (HSV) önemli bir yere sahiptir. MSS enfeksiyonu tanısında, HSV DNA'nın beyin omurilik sıvıS1 (BOS)'nda polimeraz zincir reaksiyonu (PZR) ile tespit edilmesi altın standart olarak kabul edilmektedir.Bu çalışmada 2008-2015 yılları arasında, MSS enfeksiyonu ön tanılı hastaların, ESOGÜ Tıp Fakültesi Tıbbi Mikrobiyoloji Anabilim Dalı Laboratuvarı'na gönderilen BOS örneklerinin Real time PZR sonuçları retrospektif olarak değerlendirilmiştir. Bu BOS örneklerinde DNA izolasyonu yapıldıktan sonra Artus HSV1/2 RG PCR ( Qiagen, Almanya) kitleri kullanılarak Gerçek zamanlı polimeraz zincir reaksiyonu ile Rotor Gene (Corbett Research 6000, Avustralya) cihazında HSV1/2 DNA varlığı araştırılmıştır. Kullanılan kitin analitik duyarlılığı HSV-1 ve HSV-2 için sırasıyla 120 ve $160 \mathrm{kopya} / \mathrm{mL}$ 'dir. Toplam 176 BOS örneği değerlendirilmiş olup; bu örneklerin 93'ü (\%52.8) erkek, 83’ü kadın (\%47.2) hastalara aittir. Hastaların yaş aralığı 1 74 arasında değişmektedir. Gönderilen 176 BOS örneğinin 9'unda (\%5.1) HSV-1 DNA pozitif saptanırken hiçbir BOS örneğinde HSV-2 DNA saptanmamıştır. HSV-1 DNA's1 pozitif saptanan hasta örneklerinden 4'ü Enfeksiyon Hastalıkları, 3'ü Nöroloji, 2'si ise Anestezi ve Reanimasyon kliniklerinden gönderilmiştir. SSS enfeksiyonları nadir görülmekte ancak insidansları tam olarak bilinmemektedir. HSV'ye bağlı SSS enfeksiyonlarında, etkili antiviral tedaviye başlama ve mortalitenin azaltılması açısından etkene yönelik erken tanı çok önemlidir. Bu grup hastada gerçek zamanlı PZR gibi moleküler yöntemlerin uygulamaya girmesi, tedavinin belirlenmesi açısından klinisyen hekimlere önemli oranda katkı sağlamaktadır.

Anahtar Kelimeler: Beyin omurilik sıvısı, Herpes simpleks Virüs, Real time PZR, Santral Sinir Sistemi Enfeksiyonu
\end{abstract}

Kaşifoğlu N, Aslan M, Durmaz G, Us T. 2017, Santral sinir sistemi enfeksiyonlarında, herpes simplex virüs varliğının beyin omurilik sivlsı örneklerinde real-time PZR yöntemiyle araştırılmast, Osmangazi Tıp Dergisi 2017, 39(3) 62-67 Doi: $10.20515 /$ otd.307373

\begin{abstract}
Central nervous system (CNS) infections require a rapid diagnosis and treatment approach due to their potential of rapid progression and the possibility of permanent neurological damage. Herpes simplex virus (HSV) is one of the most common causative agents of acute sporadic viral encephalitis. In diagnosis of CNS infections, the detection of HSV DNA in cerebrospinal fluid by polymerase chain reaction (PCR) is the gold standard method. In this study, HSV DNA real-time PCR results of cerebrospinal fluid samples (CSF) sent to our microbiology laboratory from patients with prediagnosis of viral CNS infection between 2008-2015 were evaluated retrospectively. A total of 176 cerebrospinal fluid samples sent to Microbiology Laboratory of Eskisehir Osmangazi University Medical Faculty between 2008-2015 were evaluated. After DNA isolation from these samples, HSV 1/2 DNA presence was evaluated with Real-time PCR technique by using Artus HSV1/2 RG PCR (Qiagen, Germany) kits on Rotor-Gene system (Corbett Research 6000, Australia). The analytical sensitivity of the kit for HSV-1 and HSV-2; 120 copies/ml and 160 copies $/ \mathrm{mL}$, respectively. Ninety three $(52.8 \%)$ patients were male and $83(47.2 \%)$ were female, ages ranging from 1 to 74 (median age 36) years. HSV-1 DNA was detected by nucleic acid testing in 9 of the 176 patients $(5.1 \%)$. Five of the $9 \mathrm{HSV}-1$ positive patients were females. Four of the positive patients were from Infection disease department, three of them from Neurology and two were from Anesthesia department. Even though CNS infections are not rare, the incidence is not clearly established. The early diagnosis of HSV infections is extremely important in CNS infections due to HSV, as specific antiviral treatment dramatically reduces the mortality. The etiology is unknown in many cases; the development of molecular techniques such as real-time PCR has increased the detection rate of viral agents.
\end{abstract}

Key Words: Cerebrospinal fluid, Herpes simplex virus, Real-time PZR, Central nervous system infection

Kasifoglu N, Aslan M, Durmaz G, Us T. 2017 , Investigation of presence of herpes simplex virus in central nervous system infections by real-time PCR method in cerebrospinal fluid samples, Osmangazi Journal of Medicine 2017, 39(3) 62-67 Doi: $10.20515 /$ otd. 307373 



\section{Giriş}

Santral sinir sistemi enfeksiyonları (SSS) hızlı ilerleyen, ölüme veya kalıcı sekellere neden olabilen ciddi seyirli hastalıklardır. Bu nedenle SSS enfeksiyonlarında hızlı tanı son derece önemlidir. Akut menenjit ve ensefalit etyolojisinde en sık karşılaşılan etkenler, virüslerdir. $\mathrm{Bu}$ etkenler arasında Herpes simpleks virüs (HSV) önemli bir yere sahiptir. Herpes simpleks virüs ensefaliti (HSVE), genel olarak sporadik nekrotizan ensefalitin en yaygin nedenlerinden biridir $(1,2)$. HSVE ateş, baş ağrısı, mental değişiklikler, nöbetler ve akut olarak gelişen fokal nörolojik defisitler ile karakterizedir (3). Primer enfeksiyon veya latent virüs reaktivasyonu ile HSV'nin beyin parankimine invazyonundan kaynaklanır. Ensefalit tipik olarak temporal lobu içerir ve manyetik rezonans görüntüleme (MRI) ile incelenebilir (4). Beyin omurilik sıvısında PZR ile HSV DNA'nın saptanması, HSVE tanısında altın standart yöntem olarak kabul edilmektedir (5). Akut HSVE ile ilişkili ölüm hızı ve morbidite, etkili antiviral tedavinin gelişmesinden önce sırasıyla $\% 70$ ve $\% 50$ iken $(3,6,7), 1980$ 'lerin ortalarında $(8,9)$ asiklovir kullanımıyla tedavi edilebilir bir hastalık haline gelmış ve HSVE ile ilişkili bir y1ll1k ölüm oranı\% 5-15'e düșmüștür $(2,10)$. Buna rağmen, nöropsikiyatrik sekeller halen yaygın olarak görülmektedir. Erken teşhis ve tedavide asiklovir kullanımı, HSVE'e bağlı mortaliteyi azaltmada oldukça etkili olmakla birlikte, kötü seyirli prognozun HSVE tanı ve tedavisinde gecikmeler nedeniyle olduğu gösterilmiştir (11). Bu nedenle, menenjit ve ensefalit tablolarının tanımlanması ve etkenin en kısa sürede belirlenmesi, tedavi yaklaşımlarını ve prognozu etkileyen temel faktörlerdir. BOS örneklerinde PZR analizi ile HSV-DNA saptaması, HSVE tanısinı koymada çok etkili olup, özgüllüğü ve duyarl11ığ1 yüksek, güvenilir bir yöntemdir.

Viral menenjit/ensefalit vakaları oldukça yaygın görülmesine rağmen genellikle yetersiz tanısal yaklaşımlar nedeniyle kesin tanı konulan vaka sayısı beklenenin çok altındadır.

\section{Gereç ve Yöntem}

$\mathrm{Bu}$ çalışmada 2008-2015 yılları arasında, SSS enfeksiyonu ön tanilı hastaların, ESOGÜ Tıp Fakültesi Tibbi Mikrobiyoloji Anabilim Dalı Laboratuvarı'na gönderilen BOS örnekleri retrospektif olarak değerlendirilmiştir. $\mathrm{Bu}$ hastalardan steril şartlar altında alınan BOS örnekleri hızlı bir şekilde laboratuvara ulaştırıldıktan sonra 1500 devirde, 20 dakika santrifüj edilmiş, gram boyama ve direkt mikroskobik inceleme yapılmıştır. Eş zamanlı bakteriyolojik kültür için kanll, EMB ve çikolata besiyerlerine ekim yapılmıştır. BOS örneklerinde DNA izolasyonu yapıldıktan sonra Artus HSV1/2 RG PCR ( Qiagen, Almanya) kitleri kullanılarak RealTime PZR yöntemi ile Rotor Gene (Corbett Research 6000, Avustralya) cihazında HSV1/2 DNA varlığ 1 araştırılmıştır. Kullanılan kitin analitik duyarlılığ $\mathrm{HSV}-1$ ve HSV-2 için sirasıyla 120 ve 160 kopya/mL'dir.

\section{Bulgular}

Toplam 176 BOS örneğinin moleküler test sonucu değerlendirilmiş olup; bu örneklerin alındığı hastaların 93'ü (\%52.8) erkek, 83'ü kadın ( \%47.2) yaş aralığı 1-74 arasında değişmektedir. Gönderilen 176 BOS örneğinin 9'unda (\%5.1) HSV-1 DNA pozitif saptanırken hiçbir BOS örneğinde HSV-2 DNA saptanmamıştır. HSV-1 DNA's1 pozitif saptanan hasta örneklerinden 4'ü Enfeksiyon hastalıkları servisine, 3'ü Nöroloji, 2'si ise Anestezi servisine aittir. $\mathrm{Bu}$ hastaların 5'i kadın hastalardan oluşmaktadır. Hastaların tıbbi kayıtlarından elde edilen mikrobiyolojik, biyokimyasal laboratuvar test sonuçları ve diğer veriler Tablo 1'de yer almıştır. Ayrıca üç hastanın çekilen MR görüntülemesi, iki hastanın ise EEG tetkikinde ensefalit ile uyumlu bulgulara rastlanılmıştır. Bir hastada ise hafiza bozukluğu sekeli bildirilmiştir. 
Tablo 1.

HSV pozitif hastaların klinik özellikleri ve çeşitli laboratuvar verileri

\begin{tabular}{|c|c|c|c|c|c|c|c|c|c|c|c|c|c|}
\hline $\begin{array}{l}\text { Hasta } \\
\text { no }\end{array}$ & Yaş/Cins & Klinik & Semptom & $\begin{array}{l}\text { HSV- } \\
\text { 1DNA }\end{array}$ & $\begin{array}{l}\text { BOS } \\
\text { Glukoz } \\
\text { (mg/dl) }\end{array}$ & $\begin{array}{l}\text { Es } \\
\text { zamanlı } \\
\text { kan } \\
\text { Glukoz } \\
\text { (mg/dL) }\end{array}$ & $\begin{array}{l}\text { BOS } \\
\text { Protein } \\
\text { (mg/dL) }\end{array}$ & $\begin{array}{l}\text { BOS } \\
\text { LDH } \\
\text { (U/L) }\end{array}$ & $\begin{array}{l}\text { BOS } \\
\text { Mikroskobisi }\end{array}$ & $\begin{array}{l}\text { BOS } \\
\text { Gram } \\
\text { boyama }\end{array}$ & $\begin{array}{l}\text { BOS } \\
\text { kültür }\end{array}$ & CRP & sağkalım \\
\hline 3 & $18 / \mathrm{E}$ & $\begin{array}{l}\text { Anestezi } \\
\text { Yoğun } \\
\text { Bakım }\end{array}$ & $\begin{array}{l}\text { Mental } \\
\text { durum } \\
\text { bozukluğu }\end{array}$ & pozitif & 62 & 86 & 54 & 120 & - & - & $\begin{array}{l}\text { Üreme } \\
\text { yok }\end{array}$ & 1.2 & sağ \\
\hline 4 & $40 / K$ & $\begin{array}{l}\text { Enfeksiyon } \\
\text { hastalıkları }\end{array}$ & $\begin{array}{l}\text { Ateş ve } \\
\text { mental } \\
\text { durum } \\
\text { bozukluğu }\end{array}$ & pozitif & 56 & 89 & 61.5 & 133 & $\begin{array}{l}60 \text { lökosit/ } \\
\mathrm{mm}^{3}\end{array}$ & $\begin{array}{l}\text { Mikroor- } \\
\text { ganizma } \\
\text { görülmedi }\end{array}$ & $\begin{array}{l}\text { Üreme } \\
\text { yok }\end{array}$ & 22.1 & sağ \\
\hline 7 & $71 / \mathrm{E}$ & $\begin{array}{l}\text { Enfeksiyon } \\
\text { hastalıkları }\end{array}$ & $\begin{array}{l}\text { Ateş ve } \\
\text { mental } \\
\text { durum } \\
\text { bozukluğu }\end{array}$ & pozitif & 83 & 135 & 65.3 & 51 & $\begin{array}{l}10 \text { lökosit/ } \\
\mathrm{mm}^{3}\end{array}$ & $\begin{array}{l}\text { Mikroor- } \\
\text { ganizma } \\
\text { görülmedi }\end{array}$ & $\begin{array}{l}\text { Üreme } \\
\text { yok }\end{array}$ & 8.3 & ex \\
\hline 8 & $40 / K$ & $\begin{array}{l}\text { Enfeksiyon } \\
\text { hastalıkları }\end{array}$ & Ateş & pozitif & 36 & 80 & 56 & 120 & - & - & $\begin{array}{l}\text { Üreme } \\
\text { yok }\end{array}$ & 0.6 & sağ \\
\hline 9 & $32 / K$ & Nöroloji & $\begin{array}{l}\text { Mental } \\
\text { durum } \\
\text { bozukluğu }\end{array}$ & pozitif & 64 & 100 & 32 & 65 & $\begin{array}{l}10 \text { lökosit/ } \\
\mathrm{mm}^{3}\end{array}$ & $\begin{array}{l}\text { Mikroor- } \\
\text { ganizma } \\
\text { görülmedi }\end{array}$ & $\begin{array}{l}\text { Üreme } \\
\text { yok }\end{array}$ & 1.8 & sağ \\
\hline
\end{tabular}


Biyokimyasal parametrelerin normal değerleri: BOS LDH (240-480U/L), BOS glukoz $(40-80 \mathrm{mg} / \mathrm{dL})$, BOS protein ( 15 $45 \mathrm{mg} / \mathrm{dL}), \mathrm{CRP}(0-0.8 \mathrm{mg} / \mathrm{L})$

\section{Tartıșma}

HSV, erişkinlerde genellikle menenjit veya ensefalite neden olan, santral sinir sisteminin önemli bir patojenidir. Yetişkinlerde HSVE, HSV tip 1 ile ilişkili nadir bir durumdur ve akut fokal nekrotizan ensefalit ile sonuçlanır ve tedavi edilmezse \% 70 gibi yüksek mortalite oranına sahiptir. Tersine, HSVM genellikle HSV-2 ile ilişkilidir ve kendiliğinden sinırlayıcı özellikte olup, terapotik tedaviye gerek kalmadan kendiliğinden düzelerek, nadiren hafif nörolojik sekellerle sonuçlanır. Klinik olarak HSVM veya HSVE şüphesi olan hastalarda, beyin omurilik sıvısı analizi en yüksek tanısal değere sahiptir ve moleküler testler tanı için "altın standart "tır. Menenjit veya meningoensefalitten şüphelenilen hastalarda, nörolojik semptomların ortaya çıktığı 1-2 gün içinde PZR ile pozitif sonuç alınabilir ve 2 ila 4 hafta arasında DNA tespiti mümkündür. Bununla birlikte viral meningoensefalit tanısında; anamnez, klinik semptom ve bulguların (prodromal grip benzeri bir sendrom bulunması, yüksek ateş, baş ağrısı, halsizlik, uykuya eğilim, major motor veya fokal nöbetler) yanı sıra BOS'un mikroskobik ve biyokimyasal incelemeleri (basınç, görünüm, lökosit sayımı ve cinsi, BOS'un gram boyalı incelenmesi, BOS protein ve şeker incelemeleri, BOS kültürleri) ve bilgisayarlı tomografi (BT) ve magnetik rezonans (MR) gibi görüntüleme yöntemleri tanıda yardımcidır (4-6).

Herpes simpleks ensefaliti sporadik fatal ensefalitin önde gelen nedenlerinden biridir. Yıllık görülme insidansı milyonda 2,5-4 vaka şeklinde olup cinsiyet ve mevsimsel fark göstermemektedir. Klinik, ateş, bilinç bulanıklığı, davranış ve mental durum bozukluğu ve lokalize nörolojik bulgularla seyreder. Lokalizasyon tipik olarak temporal lobdadır. Patognomonik bir belirtisin olmaması nedeniyle, değişen seviyelerde bilinç bulanıklığ 1 , ateş, anormal BOS bulguları ve fokal nörolojik bulguların varlığında diğer enfeksiyon etkenlerinin dışlanması HSV ensefalitini düşündürmelidir. Nükleik asit testlerinin yüksek duyarlılık ve özgüllüğü sayesinde, HSV ensefalitinin erken tanısı ile etkili antiviral ilaç tedavisi bu testlerin tanıda kullanılmasının önemini arttırmaktadır (11).

HSV, çocukluk çağında ( 3 yaşına kadar) ve 50 yaş üzeri yetişkinlerde olmak üzere iki kez artarak pik yapar. Bununla birlikte olguların çoğu 50 yaşın üzeri kişilerde görülmekte ve her iki cinsiyet eşit oranda etkilenmektedir. Çalışmamızda ise 50 yaş üstü bireyler hasta grubumuzun \%33'ünü oluşturmuş ve pozitiflik saptanan olguların yaş ortalaması 42.4 olarak belirlenmiştir, dokuz hastanın beşini kadın hastalar oluşturmuştur. Pişkin ve ark' da, olgularında belirgin bir cinsiyet hakimiyeti (\%54.3 erkek, \%46.9 kadın) tespit etmediklerini bildirmişlerdir (9).

HSV'ye bağlı santral sinir sistemi enfeksiyonu ile ilgili Türkiye'de yapılan çalışmalarda oranın \%1-19 arasında saptandiğ1 gözlenmektedir (12-15). Bu çalışmada, 176 BOS örneğinden dokuzunda (\%5.1) HSV-DNA (+) olarak saptanmıştır. Bu çalışmada belirlenen oran daha önceki çalışmalar ile karşılaştırıldığında düşüktür. Bunun nedeni, HSV DNA'nın enfeksiyonun ilerleyen günlerinde saptanmasının zorluğu, nörolojik semptomların başladıktan sonraki ilk 1-3 gün içerisinde örneğin yollanmaması ile ilişkili olabileceği veya hastaların tamamında başlanan asiklovir tedavisi sirasında gelen örnekler nedeniyle olabilir. Bu güne kadar elde edilen bulgular viral ensefalitler için en sık etyolojik ajanın HSV-1 olduğunu göstermektedir. Ülkemizde, Gültepe ve arkadaşlarının araştırmasında, bizim araștırmamızla benzer şekilde ensefalit düşünülen olguların \%5'inde HSV DNA varlı̆̆ 1 gösterilmiştir (16). Son yıllardaki bazı araştırma sonuçları ise; HSV-1 ile beraber, $\mathrm{VZV}$, enteroviruslar ve influenza virüs A gibi ajanların da ön plana çıktığını ve başlıca etyolojik faktörler arasında yer aldığını göstermektedir. Araştırmamı retrospektif olduğu için maalesef etyolojiye yönelik diğer viral etkenler araştırılamamıştır. 
BOS incelemesi tanı koydurucu değildir ama inflamatuar SSS hastalığı olduğunu teyit eder. Viral SSS enfeksiyonlarında genelde beyaz küre sayısında artış $250 / \mathrm{mm}^{3}$ '̈̈ geçmez. Enfeksiyonun erken dönemlerinde bazen nötrofil sayısında artış olsa da yaklaşık 9 saat sonra tekrarlanan lomber ponksiyon incelemelerinde lenfosit hakimiyetine doğru değişim görülür. Protein konsantrasyonu genelde en fazla $150 \mathrm{mg} / \mathrm{dL}$ 'yi geçmeyecek tarzda yükselebilir (17).

$\mathrm{Bu}$ veriyle uyumlu olarak hasta grubumuzun üçte ikisinde BOS proteini yüksek olarak saptanmıştır. Glikoz konsantrasyonu ise genelde normaldir (eş zamanlı kan glukozunun 2/3ü kadar). Bazen hafif azalma görülebilir. Hastaların \%77'sinde BOS glukozunun eş zamanlı kan glukozuna oranla azalmış olduğu belirlenmiştir.

Görüntüleme yöntemlerinden MRI ile BBT'ye göre daha erken dönemde patolojik bulgular saptanmaktadır $(4,11)$. Olgularımızın büyük çoğunluğunda patolojik EEG (\%44) ve MRI (\%66) bulguları görülmüştür.

Ülkemizden bir çalışmada 22 olgunun dördünde (\%18.2) kalıcı kişilik bozukluğu bildirilmiştir (9). Demiroğlu ve ark. (18) viral meningoensefalit ile izledikleri üç olgudan (ikisi BOS' ta PZR ile HSV-DNA gösterilen) ikisinde hafiza bozukluğu, birinde davranış bozukluğu sekeli gözlemlemiştir. Çalışmamızda ise bir hastada hafiza bozukluğu saptanmıştır.

Pişkin ve ark. (9) \%8.5, Çelik ve ark (19) ise $\% 25$ mortalite bildirmiş olup, ülkemizden bildirilen diğer iki çalışmada ise ölüm görülmemiştir $(17,18)$. Hasta grubumuzda ise bu oran 3/9 olarak belirlenmiştir. Sili ve ark.'nın toplam 106 yetişkin hastayı retrospektif olarak değerlendirdikleri çalışmada \%22 oranda sekel gelişimi görülmemiş olup; altı aylık mortalite oran $1 \% 8$ olarak bildirilmiştir.

\section{Sonuç}

Viral menenjitler; gelişmekte olan ülkelerde önemli bir sağlik sorunu olmaya devam etmektedir. $\mathrm{Bu}$ hastalarda mortalite ve morbiditeyi azaltmak için erken tanı ve tedavi çok önemlidir. $\mathrm{Bu}$ enfeksiyonlarda etkenler çoğunlukla tanımlanmamaktadır, Real-Time PCR gibi moleküler yöntemlerle viral etkenlerin hızlı, duyarlı ve özgül olarak tanınması, gereksiz antibiyotik veya antiviral kullanımını ve hastanede kalış süresini azaltmaktadır. Ayrıca epidemiyolojiye yönelik gerekli bilgi akışı sağlanarak, zamanında koruyucu önlemlerin alınmasına ve etkin tedavi yaklaşımlarına olanak sağlamaktadır. 


\section{KAYNAKLAR}

1. Glaser CA, Gilliam S, Schnurr D, et al. In search of encephalitis etiologies: diagnostic challenges in the California Encephalitis Project,1998-2000.Clin Infect Dis 2003;36:731-742.

2. Hjalmarsson A, Blomqvist P, Skoldenberg B Herpes simplex encephalitis in Sweden, 1990-2001: incidence, morbidity, and mortality. Clin Infect Dis 2007; 45: 875-880.

3. Whitley RJ. Herpes simplex encephalitis: adolescents and adults. Antiviral Res 2006;71:141-148.

4. Solbrig MV, Hasso AN, Jay CA. CNS viruses - diagnostic approach. Neuroimaging Clin N Am 2008;18:1-18.

5. Boivin G. Diagnosis of herpesvirus infections of the central nervous system. Herpes 2004;(Suppl. 2):48A-56A.

6. Tyler KL. Herpes simplex virüs infections of the central nervous system: encephalitis and meningitis, including Mollaret's. Herpes 2004;(Suppl 2):57A-64A.

7. Kimberlin DW. Management of HSV encephalitis in adults and neonates: diagnosis, prognosis and treatment. Herpes 2007;14:1116.

8. Stahl JP, Mailles A, De Broucker T. Herpes Simplex encephalitis and management of acyclovir in encephalitis patients in France. Epidemiol Infect 2012;140:372-381.

9. Pişkin N, Yalçı A, Aydemir H, Gürbüz Y, Tütüncü E, Türkyılmaz R. İkiyüzkırkdört erişkin santral sinir sistemi infeksiyonu olgusunun değerlendirilmesi. Flora 2005;10: 119-124.

10. Sili U, Kaya A, Mert A. Encephalitis Study Group. Herpes simplex virüs encephalitis: clinical manifestations, diagnosis and outcome in 106 adult patients. J Clin Virol, 2014;60:112-118.

11. Bradshaw MJ, Venkatesan A. Herpes Simplex Virus-1 Encephalitis in Adults: Pathophysiology, Diagnosis, and Management. Neurotherapeutics 2016; 13: 493-508.
12. Sayiner A, Oktem M, Ergani A, Ergon C, Kurul S, Abacioglu YH. Detection of herpes simplex virus DNA and enterovirus RNA in cerebrospinal fluid using PCR and microplate or strip hybridization assay. Clinical Microbiology and Infection 2003;9(Suppl 1), :410-419.

13. Zeytinoğlu A, Altuğlu İ, Sayıner A, ve ark Herpes ensefalitinin beyin omurilik sivis1 örneklerinden polimeraz zincir reaksiyonu ile tanıs1. Flora İnfeksiyon Hastalıkları ve Klinik Mikrobiyoloji Dergisi 2000; 5:179-182.

14. Altuglu I, Zeytinoglu A, Sirin H, Yuceyar N, Erensoy S. Comparison of different polymerase chain reaction methods for detection of herpes simplex virus types 1 and 2 encephalitis. Eur J Clin Microbiol Infect Dis 2006; 25: 669-671.

15. Soylar M, Altuğlu I, Sertöz R, Aydın, D, Akkoyun F, Zeytinoğlu A. Ege Unıversitesi Hastanesine başvuran santral sinir sistemi enfeksiyonu olgularında saptanan viral etkenler. Ege journal of medicine 2014; 53:65-70.

16. Gültepe B, Bayram Y, Güdücüoğlu $\mathrm{Y}$, Çıkman A, Berktaş M. Investigation of Bacterial and Viral Meningitis Agents with Different PCR Methods at a University Hospital. Abant Med J 2015; 4: 125-129.

17. İlhan H, Coşkun Ö, Karakaş A, Beşirbellioğu BA, Kara K, Polat EC. viral Meningoensefalit Olgularının Değerlendirilmesi. TAF Preventive MedicineBulletin 2012;11.447452

18. Demiroğlu $\mathrm{YZ}$, Turunç $\mathrm{T}$, Alışkan $\mathrm{H}$, Çolakoğlu Ş, Erdoğan AF, Arslan H. Community acquired meningitis/meningoencephalitis: retrospective evaluation of five years. Turkiye Klinikleri J Med Sci 2010; 30:218-226.

19. Çelik İ, Özden M, Kılıçoğlu A, Demirdağ K, K1lıç SS. Retrospective evaluation of 121 meningitis cases. Klimik Derg 2003;16:11-14. 